\title{
Analysis of Heavy Metals Distribution in the River Town of Hamasaki's Rod Padangsidimpuan
}

\author{
Fatma Suryani Harahap*, LailaTussifah Lubis \\ Chemical Education Department, Muhammadiyah South University, Tapanuli \\ Padangsidimpuan City North Sumatra, Jl. St. Mohd. Arief Padangsidimpuan \\ 22716 \\ *E-mail : fatmasuryani12@yahoo.com
}

\begin{abstract}
Systems of waste management in Padangsidimpuan City is an open dumping system. The location of the Padangsidimpuan City landfill is carried out at the Batu Bola TPA located in Batu Bola Village which is 120 meters from the Batang Ayumi river flow. Continuous landfill in the landfill produces pollutants in the form of leachate. Leachate contains organic materials and heavy metals. Heavy metals that are often found in leachate water are Iron $(\mathrm{Fe})$ cadmium $(\mathrm{Cd})$ and Zinc $(\mathrm{Zn})$. This research aims to know the quality of the water of the Batang Ayumi river in terms of the content of heavy metals $\mathrm{Cd}, \mathrm{Zn}$, and Fe. This research uses descriptive exploratory method by conducting a survey first. The determination of the sampling location using purposive sampling method at four stations specified. River water sampling is carried out twice, before and after rain. This research uses an Atomic Absorption Spectrophotometer tool. The data obtained were analyzed by comparing research data with water quality standards based on PP. No. 82 of 2001 to look at the conditions of the heavy metal pollution of $\mathrm{Cd}, \mathrm{Zn}$ and $\mathrm{Fe}$. The results of this study showed that the average concentration of the metal content $\mathrm{Cd}, \mathrm{Zn}$ and $\mathrm{Fe}$ werw below the specified quality threshold, namely the concentration of metal $\mathrm{Cd}$ of all stations is $0.0009 \mathrm{mg} / \mathrm{l}$, a concentration of metal $\mathrm{Fe}$ is $0.03 \mathrm{mg} / \mathrm{l}$, and concentration of $\mathrm{Zn}$ metal is $0.0002 \mathrm{mg} / \mathrm{l}$.
\end{abstract}

Keywords: Metal Cd, Fe, Zn, SSA, Batang Ayumi River

\section{Introduction}

Garbage is a serious problem in Indonesia, especially cities with high population density[1-4]. The Padangsidimpuan City is a densely populated city, every year the population in Padangsidimpuan City is always increasing. According to BPS City data in 2014 , the total population in 2012 was 198,809 people $/ \mathrm{km}^{2}$ in a period of 5 years into the future, assuming growth rates will increase by $1.03 \%$. Increasing population growth has led to increased population activities in all sectors, including housing, industry, trade and other sectors. One of the impacts of those activities is solid or garbage.

The increase in population is proportional to the increase in the amount of waste[59]. The Community consumption patterns continue to rise will produce garbage. Waste that is not managed properly will cause environmental problems. Batu Bola TPA is a garbage landfill in the Batu Bola Village, Angkola Julu District, Padangsidimuan City. This landfill serves to accommodate the garbage of the city Padangsidimpuan. Almost all villages in the city of Padangsidimpuan are crossed by the Batang Ayumi river. Only five villages of 79 villages which in no way crossed the river. Of all the villages crossed by the river there are 24 villages are there population resides on/by the River with a total 
family as much as 685 families (650 units). Currently there are still many people who use the Batang Ayumi river water such as bathing, washing and toilet[10].

The amount of garbage input in Batu Bola landfill reaches 50 tons/day. The type of waste disposed into the Batu Bola TPA is a mixture of household waste, market waste, industrial waste and hospitals[11]. Waste management in the Batu Bola Landfill using open dumping system. According to Parsons (2002) in developing countries garbage should be accommodated on site disposal that uses system sanitary landfills[10]. TPATPA are there in Indonesia is still implementing the open system of dumping, which is stacked rubbish with no geotextile and leachate layers. The result is water and air pollution around the landfill.

Site selection location of the landfill, which is 120 meters from the Batang Ayumi river flow, is also close to the Batu Bola Village settlement, which has an impact on environmental quality. One of the negative effects of the resulting water is lindi (leachate), namely liquid waste issued from biological degradation process result. Leachate is a type of water contaminants that have a high potential to pollute the environment in particular aquatic environment, good surface water such as rivers or shallow ground water. Leachate will easily be transported together with the flow of rainwater and can seep into the river flow which is located around the Padangsidimpuan City Landfill. Leachate flowing into the river can lead to a decrease in the quality of the river water.

Disposal of waste types that allow a wide range of water resulting lindi contain toxic substances and heavy metals. Heavy metals that are often found in leachate are arsenic, iron, cadmium, chromium, mercury, nickel, zinc, copper, and lead [11]. Although it is known that the presence of heavy metals in natural waters is limited in certain amount in the water column, sediment, and biota fat, but the presence of this heavy metal will increase due to water ingress into the body of the lindi River. If continually left will be bad to the quality of the river. According to the Palar (1994) that if the amount of heavy metals enter into the human body to the amount of the excess, then it will turn out to be toxic to the body function and affect the life of the life that was in the river[12].

The heavy metal content of $\mathrm{Cu}$ and $\mathrm{Pb}$ on the Batang Ayumi river flow in Padangsidimpuan City have been performed by Fatma (2018) and the results show that the Batang Ayumi river water has been contaminated with $\mathrm{Cu}$ metal with a concentration value of $0.0003-0.0904 \mathrm{mg} / \mathrm{l}[13]$. This concentration has passed the water quality standard PP No.82 of 2001, which is $0.02 \mathrm{mg} / \mathrm{l}$. According to Langmore Heavy metals which are often found in leachate are arsenic, iron, cadmium, chromium, mercury, nickel, zinc, copper, and lead. Therefore, research studies of other heavy metal studies need to be done further, so that it can be seen how much pollution the Batang Ayumi river.

\section{Research Methods}

\subsection{Tools and materials}

The tools and materials used in this this research is the nitric acid $\left(\mathrm{HNO}_{3}\right)$, distilled water and samples taken from 4 stations determined in the Batang Ayumi river flow, Atomic Absorption Spectrophotometer, thermometer, $\mathrm{pH}$ meter, electric heater. Heavy metal analysis of river water were done in environmental health Engineering Hall and disease control (BTKLPP) class 1 Medan.

\subsection{Determination of Sampling Stations}

51 |EKSAKTA: Berkala IImiah Bidang M IPA

(Science Periods EKSAKTA of MIPA) 
This research was carried out in February 2018 until April 2018 in the Batang Ayumi River flow area. The method of this research begins with identifying the possibility of problems caused by leachate from Batu Bola landfill to the Batang Ayumi river water. This research uses descriptive exploratory method by conducting a survey prior to the observation environmental conditions of Batu Bola landfill as a consideration for the impact of Batu Bola TPA on the surrounding environment. Results of the survey site then do the determination of sampling locations are determined by the method of "Purposive Random sampling".

The survey results to determine there are four points of sampling stations At each station is done two times repetition. The Station I is located in Pintu Langit Jae Village, Padangsidimpuan District, Angkola Julu and is a control station. Station II is under water disposal of landfill leachate from Batu Bola Village, Padangsidimpuan District, Batunadua. Batu Bola Village is a Padangsidimpuan City waste landfill. Station III is 7 $\mathrm{Km}$ from the Batu Bola landfill in Padangsidimpuan Batunadua District. In this area, various community activities such as bathing, washing, and latrines are found. Station IV is $13 \mathrm{Km}$ from the Batu Bola landfill located in Sihitang Village, Padangsidimpuan Tenggara District. In this area encountered a variety of community activities such as bathing, washing, latrines and bypassed the flow of waste from hospitals and factories and is downstream of the Batang Ayumi river that passed through Padangsidimpuan City.

\subsection{Research Procedure}

\subsubsection{River Water Sampling}

Samples of river water taken at the surface layer in the Middle flow of the river Batang Ayumi and then put in a plastic bottle $1.5 \mathrm{~L}$. after that each bottle plastic coded respectively. Samples ready for destruki and analyzed.

\subsubsection{Measurement sample with Atomic Absorption Spectrophotometer (AAS)}

Measurements of heavy metals is done by adding concentrated nitric acid heated to a solution almost dry and then coupled with distilled water. After that, the metal content was tested using Atomic Absorption Spectrophotometry (AAS).

\subsubsection{Data analysis}

To look the conditions of pollution of heavy metals in the water in the Batang Ayumi river, the results of heavy metal analysis compared with the water quality standard based on PP. No. 82 years of 2001 to see the conditions of the heavy metal pollution of $\mathrm{Cd}, \mathrm{Zn}$ and Fe.

\section{Results and Discussion}

\subsection{The results of measurements of river water samples with SSA}

Time river water sampling was conducted at two different time conditions, before the rain and after rain.

\section{Heavy Metal Content of The River}

Based on the measurement results of the distribution of heavy metal content Iron (Fe) has a different concentration values before the rain and after rain. The highest $\mathrm{Fe}$ metal measurement results are at station IV, which is located in Sihitang Village, South Padangsidimpuan Subdistrict, which is $0.0706 \mathrm{mg} / \mathrm{l}$ and the lowest metal content is at station I, which is located in the upstream area in Angkola Jae Subdistrict of 0.0008 mg/l. Values all the concentration of each station is obtained from the results of testing of

52 |EKSAKTA: Berkala II miah Bidang M IPA

(Science Periods EKSAKTA of MIPA) 
metallic Fe levels on the river Batang Ayumi is still under a defined quality set by PP No.82 of 2001, which is $0.3 \mathrm{mg} / \mathrm{l}$. Concentrations of Values each station For more details can be seen in Figure 1.

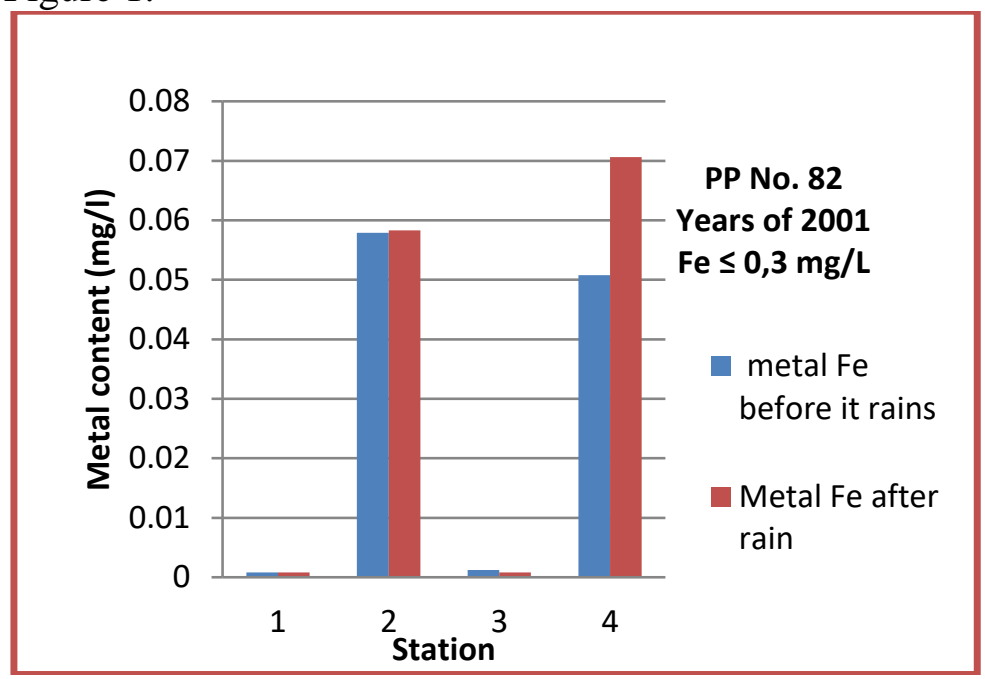

Figure 1 . The average quantity of metal Fe

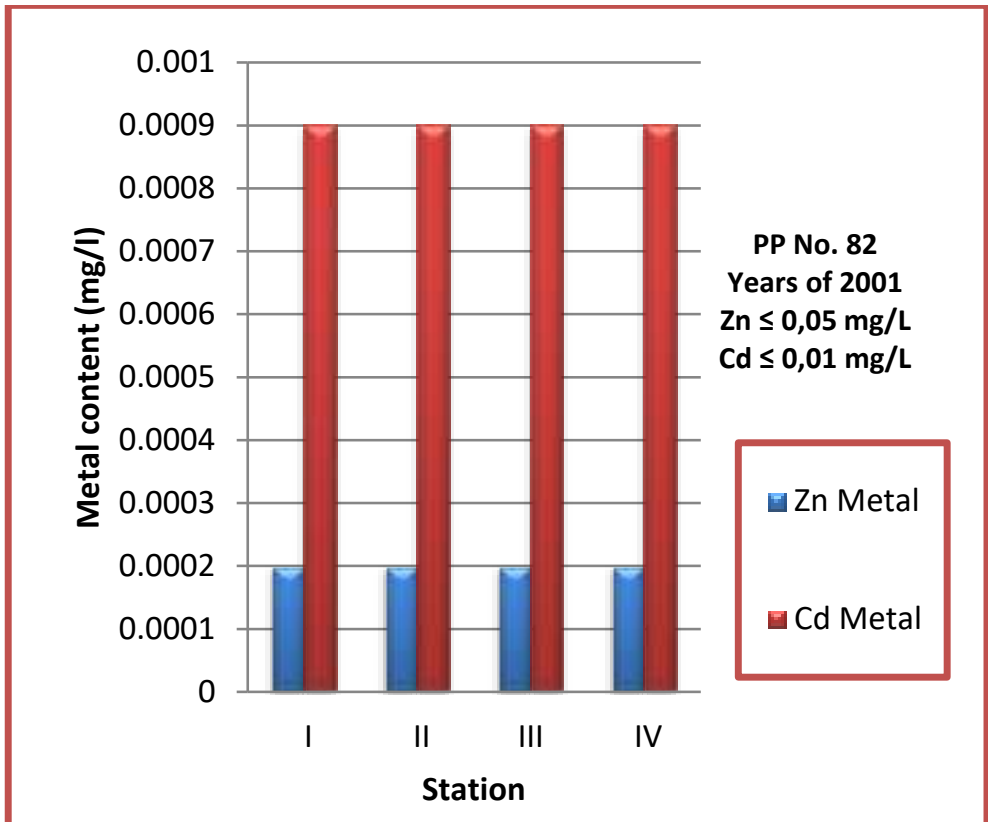

Figure 2. The average value of Metallic $\mathrm{Zn}$ and $\mathrm{Cd}$

In Figure 2 it can be seen that the content of Metal Zinc (Zn) and Cd in the Batang Ayumi river water has not broadened the raw quality in accordance with PP No. 82 of amounting to $0.05 \mathrm{mg} / \mathrm{l}$ for zinc metal and $0.01 \mathrm{mg} / \mathrm{l}$ for metal Cd. Average value of $\mathrm{Zn}$ metal concentration from each station is $0.00023 \mathrm{mg} / \mathrm{l}$ and the average value of $\mathrm{Cd}$ metal concentration was $0.0009 \mathrm{mg} / \mathrm{l}$. Research on copper metal in the Batang Ayumi river has done. Fatma (2018) concluded that the Batang Ayumi river was polluted by copper metal[13]. Can be seen in table 1 .

53 |EKSAKTA: Berkala IImiah Bidang M IPA

\section{(Science Periods EKSAKTA of MIPA)}


Table 1 . The results of the analysis of the distribution of metallic copper $(\mathrm{Cu})$

\begin{tabular}{llll}
\hline & & \multicolumn{2}{c}{ The Concentration of $\mathbf{C u}$} \\
No. & $\begin{array}{l}\text { Type Of } \\
\text { Sample }\end{array}$ & \multicolumn{1}{c}{$\begin{array}{c}\text { Before } \\
\text { The rain }\end{array}$} & $\begin{array}{l}\text { After } \\
\text { The rain }\end{array}$ \\
\cline { 3 - 4 } & & 0,0003 & 0,0422 \\
\hline 1 & Station I & 0,0003 \\
3 & Station II & 0,0807 & 0,0279 \\
4 & Station III & 0,0021 & 0,0003 \\
\hline
\end{tabular}

The distribution of copper metal is present on all the specified sampling point with two different times. It It can be seen that the copper metal concentrations in the Batang Ayumi river flow has crossed the threshold of the raw quality, due to the influence of seepage water of garbage from the Batu Bola landfill. Based on Government Regulation No. 82 of the year 2001, the maximum levels of copper metal is allowed is $0.02 \mathrm{mg} / \mathrm{L}$.

The high levels of metals of copper $(\mathrm{Cu})$ on the river due to the accumulation of litter decomposition results organic and inorganic that piled up in the Batu Bola landfill which causes the concentration of copper in the river water increased due to copper salts, such as copper carbonate $\left(\mathrm{CuCO}_{3}\right)$, copper hydroxide, $\mathrm{Cu}(\mathrm{OH})_{2}$, and copper sulfide $(\mathrm{CuS})$ is not easily soluble in water [14].

Natural process found metals and settled in nature can be derived from volcanic rocks that contributes to the environment air, water, and soil. In the body of waters, metals in general are in the form of ions, either as a couple or single-ion ion[6]. Heavy metals are divided into two types, namely the essential heavy metals are metals in certain amount of much needed by the organism. However, these metals can give rise to toxic effects if excessive amounts. For example: $\mathrm{Zn}, \mathrm{Cu}, \mathrm{Fe}, \mathrm{Co}, \mathrm{Mn}$, and others and heavy metals is not essential is a metal whose existence in the body are still unknown benefits, even the nature of the poison. For example: $\mathrm{Hg}, \mathrm{Cd}, \mathrm{Pb}, \mathrm{Cr}$, and others.

Although it is known that the presence of heavy metals in waters it is natural but if the leachate from the Batu Batu landfill was not dealt with right then did not cover the possibility of the next 5 years the river Batang Ayumi will be contaminated by many heavy metals. In addition human activities could add to the environmental pollution in the form of industrial activity, mining, fuel combustion, as well as other domestic activities capable of improving the content of metals in the environment air, water, and soil[16].

\section{Conclusion}

The existence of the Batu Bola TPA which releases leachate into the Batang Ayumi river flow has not has not led to the contamination of metals $\mathrm{Fe}, \mathrm{Zn}$ and $\mathrm{Cd}$ against the

54 IEKSAKTA: Berkala II miah Bidang MIPA

(Science Periods EKSAKTA of MIPA) 
river. It can be inferred from the data obtained states that the concentration of heavy metals content of $\mathrm{Fe}, \mathrm{Zn}$ and $\mathrm{Cd}$ is still below the threshold of government regulation of quality No. 82 year of 2001 .

\section{References}

[1] Qasemi M, Zarei A, Afsharnia M, Salehi R, Allahdadi M, Farhang M. 2018. Data on cadmium removal from synthetic aqueous solution using garbage ash. Data in brief 20:1115-23

[2] van der Werf P, Seabrook JA, Gilliland JA. 2018. The quantity of food waste in the garbage stream of southern Ontario, Canada households. PloS one 13:e0198470

[3] Walz E, Linskens E, Umber J, Culhane MR, Halvorson D, et al. 2018. Garbage Management: An Important Risk Factor for HPAI-Virus Infection in Commercial Poultry Flocks. Frontiers in veterinary science 5:5

[4] Hartmann C. 2018. Waste picker livelihoods and inclusive neoliberal municipal solid waste management policies: The case of the La Chureca garbage dump site in Managua, Nicaragua. Waste management 71:565-77

[5] Qasemi M, Zarei A, Afsharnia M, Salehi R, Allahdadi M, Farhang M. 2018. Data on cadmium removal from synthetic aqueous solution using garbage ash. Data in brief 20:1115-23

[6] van der Werf P, Seabrook JA, Gilliland JA. 2018. The quantity of food waste in the garbage stream of southern Ontario, Canada households. PloS one 13:e0198470

[7] Walz E, Linskens E, Umber J, Culhane MR, Halvorson D, et al. 2018. Garbage Management: An Important Risk Factor for HPAI-Virus Infection in Commercial Poultry Flocks. Frontiers in veterinary science 5:5

[8] Hartmann C. 2018. Waste picker livelihoods and inclusive neoliberal municipal solid waste management policies: The case of the La Chureca garbage dump site in Managua, Nicaragua. Waste management 71:565-77

[9] van Kernebeek HRJ, Oosting SJ, van Ittersum MK, Ripoll-Bosch R, de Boer IJM. 2018. Closing the phosphorus cycle in a food system: insights from a modelling exercise. Animal : an international journal of animal bioscience 12:1755-65

[10] Tauler-Ametller H, Hernandez-Matias A, Pares F, Pretus JL, Real J. 2018. Assessing the applicability of stable isotope analysis to determine the contribution of landfills to vultures' diet. PloS one 13:e0196044

[11] Nieuwenhuis E, Post J, Duinmeijer A, Langeveld J, Clemens F. 2018. Statistical modelling of Fat, Oil and Grease (FOG) deposits in wastewater pump sumps. Water research 135:155-67

[12] Alvito A, Bellodi A, Cau A, Moccia D, Mulas A, et al. 2018. Amount and distribution of benthic marine litter along Sardinian fishing grounds (CW Mediterranean Sea). Waste management 75:131-40

[13] Estay-Ossandon C, Mena-Nieto A. 2018. Modelling the driving forces of the municipal solid waste generation in touristic islands. A case study of the Balearic Islands (2000-2030). Waste management 75:70-81

55 IEKSAKTA: Berkala IImiah Bidang M IPA (Science Periods EKSAKTA of MIPA) 
[14] Akhir, 2011. Batang Ayumi River in Padang Sidempuan City: Its Conservation Starts from Sanitation Problem Solving.

[15] Langmore, A. 1998. Minimum Requirements for Water Monitoring at Waste Management Facilities, 2nd Ed. Department of Water Affairs and Forestry. Republic of South Africa.

[16] Palar, H. 1994, Heavy Metal Pollution and Toxicology, PT Rineka Cipta, Jakarta.

[17] Fatma, S.H. 2018. Metal content of $\mathrm{Pb}$ and $\mathrm{Cu}$ in the Batang Ayumi Watershed in Padangsidimpuan City, North Sumatra. Proceedings.

[18] Effendi, H. 2003. Review of Water Quality for the Management of Resources and the Aquatic Environment. Kanisius publisher. Yogyakarta.

[19] Dwika, I.M and Indah, R.S. 2012. Profile of Heavy Metal Pollution Distribution in Water and River Flow Sediments from TPA Sari Mukti Lindi Water. Journal of Environmental Engineering. Volume 18. Number 1. pg. 30-42.

[20] Widowati, et al. 2008. Metal Toxic Effects: Prevention and Control of Pollution. Andi publisher. Yogyakarta.

56 IEKSAKTA: Berkala IImiah Bidang MIPA

(Science Periods EKSAKTA of MIPA) 